\title{
Adolescents' Use of Maternal and Child Health Services In Developing Countries
}

By Heidi W. Reynolds, Emelita L. Wong and Heidi Tucker

Heidi W. Reynolds is senior research associate, Emelita L. Wong is associate director of biostatistics and Heidi Tucker is biostatistician, Family Health International/YouthNet, Research Triangle Park, NC, USA.

CONTEXT: Because of high levels of early childbearing in developing countries, pregnancy and childbirth are the leading causes of death among women aged 15-19. Use of skilled antenatal and delivery care improves maternal outcomes through the prevention, management and treatment of obstetric complications, and infant immunizations prevent many childhood diseases.

METHODS: Logistic regression analysis of Demographic and Health Survey data for 15 developing countries examined adolescents' use of antenatal care, delivery care and infant immunization services compared with use by older women.

RESULTS: In general, the use of maternal and child health care did not vary by mother's age. In five of the 15 countries, women aged 18 or younger were less likely than women aged 19-23 to use either antenatal care or delivery care, or both (odds ratios, 0.5-0.9). Younger mothers in six countries were less likely than older mothers to have their infants immunized, particularly for diphtheria, pertussis and tetanus and for measles (0.5-0.8). The association of age and health care use was largely limited to Bangladesh, India, Indonesia, Nicaragua, Peru and Uganda. In Latin America, controlling for parity allowed differences between adolescents and older women to emerge. Except in Uganda, there were no differences in health care use by mother's age in the African countries.

CONCLUSION: Country-specific investigations are needed in Asia to better understand the reasons for differences in service use by age. In general, further systematic evidence would help identify long-term interventions that will be most effective in increasing adolescents' use of maternal and child health services.

International Family Planning Perspectives, 2006, 32(1):6-16

In parts of the developing world where fertility rates are high, teenage pregnancy and early marriage are common. Worldwide, adolescents have more than 14 million births each year, and more than $90 \%$ of these occur in developing countries. ${ }^{1}$ The proportion of teenage women who are mothers or are currently pregnant is greatest in Sub-Saharan Africa (20-40\%). ${ }^{2}$ The proportions are lower in other regions: 6-21\% in Asia - with Bangladesh an outlier at 35\%-and 13-25\% in Latin America.

As a result of high levels of early childbearing in developing countries, pregnancy and childbirth are the leading causes of death among women aged $15-19 .{ }^{3}$ Compared with older women, teenagers are at increased risk for poor maternal and infant outcomes, ${ }^{4}$ particularly maternal death and having an infant who is low-birth-weight or dies. ${ }^{5}$ The risk of maternal death during childbirth is $2-4$ times as high among adolescents younger than 18 as among women aged 20 or older. ${ }^{6}$ Compared with babies born to women aged 20-29, babies born to women younger than 20 have a 34\% higher risk of death in the neonatal period, largely because of their increased risk of being low-birth-weight, ${ }^{7}$ and a $26 \%$ higher risk of death by age five. ${ }^{8}$

Determinants of poor maternal and infant outcomes include poverty; cultural factors that restrict women's autonomy, promote early marriage or support harmful traditional practices; nutritional deficiencies; reproductive factors such as young age at first birth; distance to health services; and inadequate health care behavior or use of services. ${ }^{9}$ Pregnant adolescents are disproportionately affected by these factors. ${ }^{10}$ Programs to delay first births to adolescents would mitigate risks to maternal and infant health associated with maternal factors such as short height, low weight and inadequate nutrition, but it is not clear how delaying first births would affect the social advantages or disadvantages of early childbearing. For example, adolescents who become pregnant may cut their education short because they are forced to leave school. Yet early childbearing may improve a woman's social status because in some cultures it is an important step toward marriage.

For all women, use of health care services is a key proximate determinant of maternal and infant outcomes, ${ }^{11}$ including maternal and infant mortality. ${ }^{12}$ Moreover, the benefits of health care-seeking and positive health behaviors are relatively strong in settings and subgroups where socioeconomic and public health resources are constrained. ${ }^{13}$ Timely and appropriate care can provide an opportunity to prevent or manage the direct causes of maternal mortality-hemorrhage, obstructed labor, unsafe abortion, infection and hypertensive disorders-and to reduce fetal and neonatal deaths related to obstetric complications. ${ }^{14}$ 
Antenatal care can improve certain outcomes through the detection and management of and referral for potential complications, ${ }^{15}$ although such care has not been shown to reduce rates of maternal mortality. Evidence from developed countries suggests that adequate antenatal care may improve birth weight. ${ }^{16}$ Antenatal care can also prevent, identify and treat iron deficiency and anemia in adolescent mothers, ${ }^{17}$ severe anemia has been linked to maternal and child mortality. ${ }^{18}$ Furthermore, women who are pregnant for the first time-including most pregnant adolescentsare more susceptible than women with higher-order pregnancies to malarial parasitic infection, ${ }^{19}$ which is associated with anemia, abortion, stillbirth, premature birth and low birth weight. ${ }^{20}$ Antenatal care is an appropriate venue for the primary prevention of malaria (through providers' counseling and the use of bed nets or chemoprophylaxis) or prompt diagnosis and treatment. Care during pregnancy can provide an entry into the health system, and for adolescents in particular, such care may be one of the first comprehensive health assessments they receive. The provision of antenatal care also presents an opportunity to teach adolescents how to recognize and respond to the signs of obstetric complications. ${ }^{21}$

Delivery services, especially emergency obstetric care, are also critical for pregnant women. Emergency care is important if adolescents experience obstructed labor, pregnancy-induced hypertension, eclampsia or severe untreated anemia. Obstructed or prolonged labor is one of the more serious complications that can cause maternal morbidity and death, and adolescents appear to be at higher risk than are older women, ${ }^{22}$ because their pelvic bones and birth canals are not completely developed. Obstetric care can also prevent or treat complications that affect the neonate, such as birth asphyxia. ${ }^{23}$

The postpartum period is a critical time for mother and newborn. However, few data are available to assess whether adolescents use postpartum care. Data are also scarce on postpartum care use for the mother's health, but those that do exist suggest that coverage is low. ${ }^{24}$ Demographic and Health Survey (DHS) data document postpartum care for women who did not deliver in health facilities; for women who did, the surveys assume that both mothers and infants received some care. ${ }^{25}$ For the infant, immunizations are one of the most cost-effective interventions to reduce vaccinepreventable diseases. ${ }^{26}$

Delays in seeking care, in reaching adequate health facilities and in receiving appropriate care at facilities are wellknown barriers to care for all women, ${ }^{27}$ and these factors may be especially pronounced for youth, who may have little knowledge and experience in seeking care. In some places_rural Bangladesh, for example-family members often expect adolescents to give birth at home with traditional birth attendants, and young women have little or no influence on the decision. ${ }^{28}$

Adolescents have increased risk for poor maternal and infant outcomes, and it is widely assumed that they are less likely than older women to use services. Yet the evidence on their use of maternal care services is limited and mixed. Unadjusted analyses of DHS data found that women younger than 18 were less likely than women aged 18-34 to seek antenatal care from a health professional in 19 of 26 countries (in six of these countries, the difference was more than eight percentage points). ${ }^{29}$ Younger women were also less likely to seek delivery care from a health professional in 17 of 28 countries (in five of these countries, the difference was more than seven percentage points). Another analysis found that in four of seven study countries, the proportion of women younger than 20 using maternal and child health services (measured as a composite variable) was lower than the proportion among women aged 20-29 (although no statistical tests were reported). ${ }^{30}$ Furthermore, multivariable analyses of urban data from Bobo-Dioulasso, in Burkina Faso, and Bamako, in Mali, found that women younger than 18 were significantly less likely to seek early or any antenatal care than were women aged 24-39. ${ }^{31}$

Differences between adolescent and older mothers' use of infant services, specifically immunizations, are no clearer. Analyses of DHS immunization data from 1986 to 1989 found that in 11 of 21 countries, children aged 12-35 months born to mothers younger than 20 were less likely to ever have been vaccinated than were the children of mothers aged 20-34. ${ }^{32}$ Although no statistical tests were presented, the difference was five percentage points or more in five of the 11 countries. One study that did control for confounding factors found that children born to urban teenagers in Mali and Burkina Faso were significantly less likely to be vaccinated than were children born to mothers aged 25-29.33

To investigate associations between poor health outcomes and early childbearing, we examined adolescent mothers' use of maternal and child health services in developing countries. We assessed their use of antenatal care, delivery care and infant immunization services relative to that of older women, taking into account factors that may mediate the relationship between age and use of services.

\section{METHODS}

Data Sources

This study uses data from the DHS series, which are nationally representative household surveys that collect data on a wide range of indicators in the areas of population, health and nutrition. The surveys employ national probability samples of households and, in general, use a two-stage sampling strategy. They first randomly sample geographic units or enumeration areas, and then select households with a known probability.

We explored adolescents' use of maternal and child health services in 15 countries in three geographic regions. We used a three-stage process to identify study countries. First, countries were limited to those with a DHS conducted after 1992, because recent data are more relevant to making policy and programmatic recommendations, and because 1992 demarcates the end of DHS-II surveys and the beginning of DHS-III and DHS+ surveys, thus allowing us to use similar 


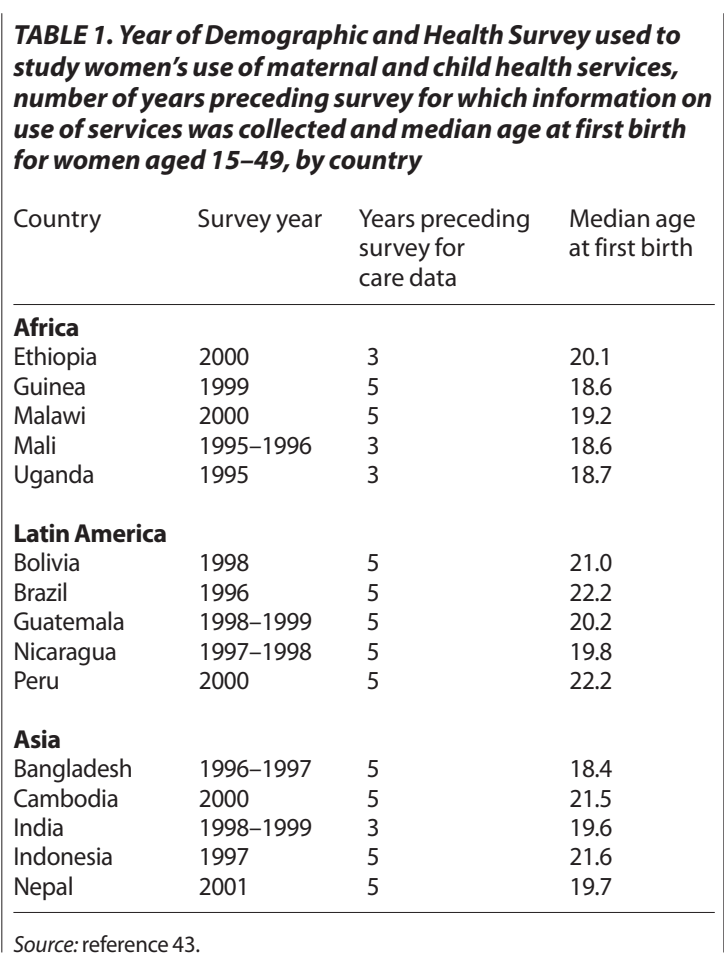

DHS data sets. Next, three regions of interest were identified: Sub-Saharan Africa, Latin America and South Asia. Finally, we chose the five countries in each region with the best combination of large sample size and low median age at first birth (Table 1), to achieve the largest possible samples of women who gave birth as adolescents, while remaining consistent with our aim of having geographic variation.

The surveys collect information from women on their pregnancies and births, and on their use of maternal and child health services in the three or five years preceding the survey. We examined data on women aged 15-23 at the time of the survey with a birth in the previous three or five years, and their children born in the same periods. In Bangladesh, India, Indonesia and Nepal, survey data were limited to children born to ever-married women.

\section{Dependent Variables}

We used one indicator of antenatal care, one of delivery care and four of infant vaccinations. For antenatal care, we created a dichotomous variable that indicated whether women had seen a skilled health care provider (defined as a doctor, person with midwifery training or "country-specific health professional") at least once during pregnancy, because skilled providers should be able to identify women at risk for obstetric complications and offer appropriate care or referrals. This measure is equivalent to the World Health Organization definition of antenatal care. ${ }^{34}$ Women who reported receiving no antenatal care, as well as those reporting a visit only with a traditional birth attendant (trained or untrained), a relative or another person, were considered to have received no care from skilled personnel.

As an indicator of delivery care use, we assessed whether women had a skilled delivery attendant, defined as a per- son with midwifery skills (e.g., doctor, midwife or nurse) who had received the training necessary to manage normal delivery and to diagnose, manage or refer complications. ${ }^{35}$ Although it is preferable to measure "skilled attendance"defined as care from a skilled attendant in an enabling environment that includes adequate supplies, equipment, systems of communication and referral services ${ }^{36}$ - the survey data do not provide this information. Our measure was preferred to "delivery in a health facility" for three reasons: because a skilled attendant presumably is linked with emergency obstetric care, ${ }^{37}$ because skilled attendance at delivery is widely used as an indicator in service evaluations ${ }^{38}$ and because delivery with a skilled attendant appears to be an important characteristic associated with low mortality at the country level. ${ }^{39}$

Our four immunization indicators were based on the World Health Organization's recommended infant vaccination schedule. ${ }^{40}$ The Bacillus Calmette-Guérin (BCG) vaccination, which protects against tuberculosis, is typically administered at birth. Polio and diptheria, pertussis and tetanus (DPT) vaccinations are administered in three doses, at six weeks, 10 weeks and 14 weeks (we focused on the third dose of each). Measles vaccination is given once, at nine months. For this study, an infant was considered immunized against the particular illness if the information was obtained from the child's health card (i.e., the immunization record filled out by health workers and kept by mothers) or the mother's report; these reports were used in DHS surveys when health cards were not available. As expected, the majority of immunizations were based on reports. ${ }^{41}$

For antenatal care and delivery care with skilled providers, the unit of analysis was the mother. Selecting the woman as the unit of analysis, rather than the child, standardizes the definition of antenatal care with a skilled attendant across countries, because information about such care is limited to last births in Ethiopia, Malawi, Peru, Cambodia and Nepal. In addition, study countries are at different stages in the demographic transition, and thus vary with respect to birthspacing intervals and age-specific fertility rates. Moreover, because women's socioeconomic characteristics were measured only at the time of the interview, they would be more temporally correlated to the time of last birth than to previous births.

For the four immunization indicators, the unit of analysis was the infant. Analyses were conducted for all infants aged 12 months or older born to women within the three or five years preceding the survey. Limiting the age of infants avoids problems associated with censoring. Focus on the infant is appropriate when the objective is to analyze the level of coverage for a sample of live-born infants, as it helps quantify the level of protection provided. ${ }^{42}$

A small proportion of women had twins (or triplets); we excluded one of the twin (or two of the triplet) observations at random for the antenatal care and delivery measures, as data for the mother will be the same. However, twins and triplets were treated as independent observations for the immunization variables, because some factors could result in siblings' being treated differently. 


\section{Independent Variables}

Several covariates were examined because they may mediate the relationship between age and use of maternal and child health care. We calculated the mother's age at the time of birth by subtracting her infant's age from her age at the time of the survey. We defined older women as the age-group 19-23, considering this to be the "optimal" childbearing interval because the risk of pregnancy complications is lower than for other age-groups, the age-specific fertility rate is highest (in 11 of the 15 study countries) ${ }^{43}$ and fecundity is at its peak. ${ }^{44}$ Thus, in this age-group the risk of physiological consequences of childbearing is at its lowest level, and childbearing in this age range is also more socially acceptable, particularly in developing country settings.

Because of sample size limitations, most studies combine adolescents into a single age-group, despite the known emotional, physical and social differences between younger and older adolescents. Before selecting an adolescent age-group, we conducted bivariable analyses of age and the dependent variables to assess these differences; these results led us to choose women aged 18 or younger as the main focus for the multivariable analyses. We split this age-group into women 16 or younger and those 17-18 for three of the countries.

Marital status was examined because unmarried adolescents are less likely to use antenatal care than are married adolescents, particularly in Latin America and Asia. ${ }^{45}$ In general, women with premarital births are less likely than those with marital births to have obtained antenatal care or to seek later care. ${ }^{46}$ Furthermore, premarital births are most likely to occur in the teenage years. Married women may be more inclined to seek antenatal care for a number of reasons, including being in a better economic position, having more familial and community support, and having someone to take care of their children while visiting health services. ${ }^{47}$ In some settings, however, particularly in SubSaharan Africa, the transition from being single to being married is not a distinctly defined event; couple formation is conducted in stages, and childbearing is one step in the process. ${ }^{48}$ The survey data did not allow us to assess the more subtle stages of marriage. Nonetheless, the assumption that married women get more support than unmarried women has been questioned for adolescents, because in some countries, younger age at marriage is associated with a greater age difference between spouses, less choice about one's spouse and less decision-making power. ${ }^{49}$

In the multivariable analysis for Africa and Latin America, marital status was dichotomously measured as currently married versus formerly married or never-married. Currently married included women living with a partner; formerly married included widowed, divorced and separated women, as well as women who no longer lived with a partner. For Asia, marital status was either currently married or formerly married.

It is important to control for parity because it is highly correlated with maternal age, and first pregnancies carry risks independent of maternal age. ${ }^{50}$ Also, adolescents are more likely than older women to be in their first pregnancies. This variable was dichotomized between having had one birth and having had two or more.

Education is associated with improved maternal and child health, ${ }^{51}$ and teenage pregnancy is concentrated among adolescents with relatively low levels of education. ${ }^{52}$ Education is also associated with the likelihood that mothers are able to produce a health card with infant immunization information, ${ }^{53}$ inclusion of this variable may help control reporting biases introduced by respondent recall. For Asia and Latin America, education was divided into none, primary, and secondary or higher for the multivariable analysis. For Africa, this variable was dichotomized into none versus some education. Surveys in nine countries asked whether respondents were still in school; this variable was included in the multivariable analysis for Bolivia, Brazil, Guatemala and Nicaragua.

This study relies on place of residence as an indicator of access to care, and it is associated with use of health services. ${ }^{54}$ In the bivariable analysis, four categories were used: capital or large city, small city, town and rural area. We divided residence into three categories for multivariable analysis: capital city, small city or town, and rural area.

Cultural factors may limit or encourage care-seeking behavior. ${ }^{55}$ To control for these factors, we included the most relevant available variable: ethnicity (Guinea, Malawi, Mali, Brazil, Guatemala and India), religion (Ethiopia, Uganda, Bangladesh, Cambodia, Indonesia and Nepal) or language spoken at home (Bolivia and Peru). None of these variables was available for Nicaragua.

Sex of the infant was included in the multivariable analyses of immunizations, because in some countries resources may be allocated to favor male infant access to these services. ${ }^{56}$

Poverty is strongly associated with antenatal care, delivery attendance and immunization coverage. ${ }^{57}$ To control for socioeconomic status, we used the World Bank's household asset index. ${ }^{58}$ We combined the lower two quintiles and the middle two quintiles of households to yield a threelevel variable, in which the lowest $40 \%$ represented the "poor" category, the middle $40 \%$ the "middle" category and the upper 20\% the "rich" category. At the time of this study, asset indices were not available for Ethiopia, Malawi, Bolivia, Guatemala, Peru or Indonesia. In these cases, we computed asset scores for each household using SAS version 8 and the formula used by the World Bank. ${ }^{59}$

\section{Statistical Analysis}

Descriptive statistics were obtained for the social and demographic characteristics of women aged 15-23 who had had a child in the three or five years preceding the surveys. Cross-tabulations were used to examine the bivariable relationships by country between mother's age at the time of birth and the dependent variables. No significance testing was conducted on these statistics.

For the multivariable analyses, survey-based logistic regression models were used to calculate odds ratios and 95\% 
TABLE 2. Sample sizes used in analyses of maternal and child health care, by mother's age at last birth, according to country

Country

Women receiving caret $\mid$ Infants immunized $(\geq 12$ mos. old $)$

\section{Africa}

Ethiopia

Guinea

Malaw

Mali

Uganda

\begin{tabular}{lllll}
\hline $15-16$ & 17 & 18 & $19-23$ & Total
\end{tabular} 15-16 $17 \quad 18 \quad 19-23 \quad$ Total

Latin America

\begin{tabular}{llllll|lllll} 
Bolivia & 103 & 123 & 160 & 1,110 & 1,496 & 173 & 149 & 224 & 1,474 & 2,020
\end{tabular}

\begin{tabular}{llllll|lllll} 
Brazil & 181 & 137 & 178 & 1,041 & 1,537 & 221 & 155 & 213 & 1,172 & 1,761
\end{tabular}

$\begin{array}{lllllllllll}\text { Guatemala } & 118 & 104 & 139 & 849 & 1,210 & 226 & 156 & 198 & 1,156 & 1,736\end{array}$

$\begin{array}{llllllllllll}\text { Nicaragua } & 383 & 283 & 304 & 1,657 & 2,627 & 506 & 346 & 390 & 1,988 & 3,230\end{array}$

\begin{tabular}{llllll|lllll} 
Peru & 337 & 319 & 446 & 2,706 & 3,808 & 382 & 368 & 476 & 3,021 & 4,247
\end{tabular}

Asia

$\begin{array}{lllllllllll}\text { Bangladesh } & 561 & 254 & 259 & 1,463 & 2,537 & 690 & 258 & 314 & 1,623 & 2,885\end{array}$

\begin{tabular}{lrrrrr|rrrrr} 
Cambodia & 58 & 103 & 160 & 1,041 & 1,362 & 88 & 146 & 192 & 1,324 & 1,750
\end{tabular}

$\begin{array}{lllllllllll}\text { India } & 1,081 & 1,003 & 1,558 & 10,800 & 14,442 & 950 & 830 & 1,286 & 8,409 & 11,475\end{array}$

\begin{tabular}{llllll|lllll} 
Indonesia & 228 & 300 & 458 & 3,666 & 4,652 & 281 & 329 & 485 & 3,929 & 5,024
\end{tabular}

\begin{tabular}{llllll|lllll} 
Nepal & 126 & 149 & 217 & 1,514 & 2,006 & 185 & 222 & 284 & 1,918 & 2,609
\end{tabular}

†Skilled antenatal or delivery care.

confidence intervals, controlling for all of the independent variables. Because of unequal probabilities in the selection of households, women and births in the sampling designs of the different surveys, these analyses were conducted using the sampling weight for each birth. SUDAAN version 8.0 was used to account for the stratification, clustering and unequal probabilities of selection of study participants. ${ }^{60}$ Results for the multivariable analyses of the control variables are available from the author.

\section{RESULTS}

\section{Sample Characteristics}

Distributions of the study populations by maternal age are presented in Table 2. Women's social and demographic characteristics varied across the 15 countries, but differences were most noticeable at the regional level (Table 3).

The mean age of respondents was similar in all surveysbetween 19.8 and 20.8 (not shown). The vast majority of mothers (73-99\%) were currently married or living with a partner, which is consistent with observations that the majority of childbearing occurs within marriage. ${ }^{61}$ In African and Asian countries, relatively small proportions of women were formerly married (1-10\%). In Latin America-particularly in Bolivia, Brazil and Peru-the proportion of mothers who were never-married (14-17\%) was relatively high compared with the proportion in Africa (2-9\%).

Approximately one-half of mothers had had one birth, although this proportion was greater in Brazil (63\%), Peru (68\%), Cambodia (64\%) and Indonesia (78\%). Education levels were lowest in Africa, moderate in Asia and relatively high in Latin America. For countries where data were available, larger proportions of mothers in Latin America were still in school at the time of the surveys (12\% in Bolivia and Brazil). In Africa and Asia, most women lived in rural areas (71-91\%). In Latin America, especially in Bolivia, Brazil and Peru, greater proportions of mothers lived in a city (54-59\%).

\section{Bivariable Analysis}

Unweighted regional averages of the proportion of women using maternal and child health care suggest a positive relationship between increasing mother's age at last birth and

| TABLE 3. Percentage distribution of women who gave birth at ages $15-23$, by selected characteristics, according to country

\begin{tabular}{|c|c|c|c|c|c|c|c|c|c|c|c|c|c|c|c|}
\hline \multirow[t]{2}{*}{ Characteristic } & \multicolumn{5}{|l|}{ Africa } & \multicolumn{5}{|c|}{ Latin America } & \multicolumn{5}{|l|}{ Asia } \\
\hline & Ethiopia & Guinea & Malawi & Mali & Uganda & Bolivia & Brazil & $\begin{array}{l}\text { Guate- } \\
\text { mala }\end{array}$ & $\begin{array}{l}\text { Nica- } \\
\text { ragua }\end{array}$ & Peru & $\begin{array}{l}\text { Bangla- } \\
\text { desh }\end{array}$ & $\begin{array}{l}\text { Cambo- } \\
\text { dia }\end{array}$ & India & $\begin{array}{l}\text { Indo- } \\
\text { nesia }\end{array}$ & Nepal \\
\hline \multicolumn{16}{|l|}{ Marital status } \\
\hline Currently married & 90 & 91 & 84 & 90 & 84 & 78 & 73 & 84 & 75 & 74 & 98 & 93 & 99 & 96 & 99 \\
\hline Formerly married & 9 & 3 & 10 & 2 & 9 & 8 & 12 & 10 & 23 & 9 & 2 & 7 & 1 & 4 & $<1$ \\
\hline Never-married & 2 & 6 & 6 & 9 & 7 & 14 & 15 & 6 & 2 & 17 & $\mathrm{u}$ & $\mathrm{u}$ & $\mathrm{u}$ & $\mathrm{u}$ & $\mathrm{u}$ \\
\hline \multicolumn{16}{|l|}{ Parity } \\
\hline 1 & 53 & 53 & 54 & 47 & 46 & 57 & 63 & 48 & 54 & 68 & 53 & 64 & 49 & 78 & 55 \\
\hline$\geq 2$ & 47 & 47 & 46 & 53 & 54 & 43 & 37 & 51 & 46 & 32 & 47 & 36 & 51 & 22 & 45 \\
\hline \multicolumn{16}{|l|}{ Education } \\
\hline None & 79 & 83 & 18 & 84 & 22 & 4 & 4 & 26 & 17 & 3 & 49 & 31 & 51 & 3 & 58 \\
\hline Primary & 15 & 12 & 72 & 13 & 68 & 41 & 35 & 56 & 49 & 37 & 31 & 52 & 18 & 65 & 20 \\
\hline$\geq$ secondary & 6 & 5 & 10 & 3 & 10 & 55 & 60 & 17 & 34 & 60 & 20 & 17 & 31 & 32 & 22 \\
\hline \multicolumn{16}{|l|}{ Still in school } \\
\hline Yes & $\mathrm{u}$ & 3 & $\mathrm{u}$ & 1 & $<1$ & 12 & 12 & 4 & 9 & $\mathrm{u}$ & $\mathrm{u}$ & $\mathrm{u}$ & $<1$ & 1 & $\mathrm{u}$ \\
\hline No & $\mathrm{u}$ & 97 & $\mathrm{u}$ & 99 & 99 & 88 & 88 & 96 & 91 & $\mathrm{u}$ & $\mathrm{u}$ & $\mathrm{u}$ & 99 & 99 & $\mathrm{u}$ \\
\hline \multicolumn{16}{|l|}{ Place of residence } \\
\hline Capital/large city & 2 & 15 & 5 & 13 & 7 & 42 & 32 & 8 & 22 & 44 & 5 & 3 & 4 & 5 & 1 \\
\hline Small city & 2 & 4 & 7 & 10 & 3 & 17 & 22 & 20 & 16 & 10 & $<1$ & 4 & 6 & 7 & 0 \\
\hline Town & 7 & 10 & 3 & 6 & 3 & 6 & 23 & 12 & 18 & 0 & 4 & 8 & 9 & 12 & 8 \\
\hline Rural area & 89 & 71 & 85 & 71 & 87 & 35 & 23 & 61 & 44 & 46 & 91 & 85 & 80 & 77 & 91 \\
\hline Total & 100 & 100 & 100 & 100 & 100 & 100 & 100 & 100 & 100 & 100 & 100 & 100 & 100 & 100 & 100 \\
\hline
\end{tabular}


TABLE 4. Percentage of women who used skilled maternal and child health care, by age at last birth, according to region

\begin{tabular}{|c|c|c|c|c|c|c|c|c|c|c|c|c|c|c|c|c|c|c|c|c|c|c|c|c|}
\hline \multirow[t]{2}{*}{ Region } & \multicolumn{4}{|c|}{ Antenatal care } & \multicolumn{4}{|c|}{ Delivery care } & \multicolumn{4}{|c|}{$B C G$} & \multicolumn{4}{|c|}{ DPT } & \multicolumn{4}{|c|}{ Measles } & \multicolumn{4}{|c|}{ Polio } \\
\hline & $\begin{array}{l}15- \\
16\end{array}$ & 17 & 18 & $\begin{array}{l}19- \\
23\end{array}$ & $\begin{array}{l}15- \\
16\end{array}$ & 17 & 18 & $\begin{array}{l}19- \\
23\end{array}$ & $\begin{array}{l}15- \\
16\end{array}$ & 17 & 18 & $\begin{array}{l}19- \\
23\end{array}$ & $\begin{array}{l}15- \\
16\end{array}$ & 17 & 18 & $\begin{array}{l}19- \\
23\end{array}$ & $\begin{array}{l}15- \\
16\end{array}$ & 17 & 18 & $\begin{array}{l}19- \\
23\end{array}$ & $\begin{array}{l}15- \\
16\end{array}$ & 17 & 18 & $\begin{array}{l}19- \\
23\end{array}$ \\
\hline $\begin{array}{l}\text { Africa } \\
\text { Latin }\end{array}$ & 69 & 70 & 67 & 67 & 42 & 41 & 39 & 36 & 79 & 77 & 78 & 75 & 52 & 50 & 51 & 52 & 59 & 59 & 60 & 60 & 53 & 51 & 55 & 53 \\
\hline America & 72 & 71 & 75 & 74 & 67 & 66 & 65 & 68 & 91 & 92 & 94 & 94 & 70 & 75 & 75 & 78 & 83 & 85 & 84 & 86 & 67 & 69 & 70 & 73 \\
\hline Asia & 56 & 59 & 60 & 59 & 23 & 26 & 33 & 33 & 76 & 80 & 80 & 81 & 60 & 61 & 62 & 67 & 63 & 66 & 67 & 70 & 69 & 71 & 70 & 72 \\
\hline
\end{tabular}

Notes: Percentages are unweighted. Immunizations for DPT and polio are for the third shot in each series.

the care measures in Asia and, to a lesser extent, in Latin America (Table 4). For Africa, however, the unweighted averages suggest a decrease in the use of maternal and child health care by older mothers, particularly for skilled delivery care and BCG immunization. The proportion of young mothers reporting delivery care varied widely among the regions, being lowest in Asia (23-33\%) and Africa (36-42\%), and highest in Latin America (65-68\%).

Bivariable analysis also suggests country-level differences between women aged 18 or younger and women aged 19-23 in their use of maternal health care (Table 5) and child health care (Table 6 , page 12). In 16 cases, the proportion of older women using these services was 10 percentage points or greater than that of adolescents in at least one of the three younger subgroups. Of these cases, eight were in Asia (India and Indonesia), five in Latin America (Guatemala and Peru) and three in Africa (Uganda). Most differences of this magnitude involved infant immunizations.

In 12 countries, the bivariable results did not reveal many large differences between younger and older adolescents. For these countries, the multivariable analyses compared all mothers aged 18 or younger with those aged 19-23. In three countries-Peru, India and Indonesia-the differences between the youngest adolescents and each of the older adolescent subgroups were large enough (up to 20 percentage points) and consistent enough across measures to allow for multivariable analysis not only of adolescents aged 18 or younger as a group, but of 15-16-year-olds and 17-18-yearolds as subgroups.

\section{Multivariable Analysis}

- Skilled maternal health care. In four countries, adolescents' and older women's use of skilled antenatal care differed significantly (Table 7, page 13). In one Latin American country (Nicaragua) and three Asian countries (Bangladesh, India and Indonesia), adolescents aged 18 or younger were significantly less likely than women aged 19-23 to use antenatal care (odds ratios, 0.6-0.9). When the adolescents were disaggregated into two subgroups, only those 16 or younger in India and 17-18-year-olds in Indonesia had significantly reduced odds of using antenatal care (0.8 and 0.5 , respectively).

In four countries (one in Latin America and three in Asia), adolescents 18 or younger were significantly less likely than older mothers to use skilled delivery care (odds ratios, 0.5-0.8). Differences in care between each adolescent subgroup and older mothers in India and Indonesia were sig- nificant. Notably, adolescents were significantly more likely than older women to use skilled delivery care in Bolivia (1.6).

For Brazil, few differences between age-groups were found in the bivariable analyses, yet multivariable analysis found that younger mothers were less likely than older mothers to use skilled delivery care (odds ratio, 0.6). To explain this finding, we evaluated the adequacy of the covariate cell sizes to confirm that controlling for confounding factors-in this case, parity-allowed a stronger association between age and delivery care to emerge.

-Infant immunization. Compared with the maternal care results, multivariable findings for the immunization measures revealed many more significant differences between infants born to adolescents and infants born to older women (Table 8, page 13). Infants born to adolescents in Nicaragua and India were less likely to receive BCG vaccinations than were infants born to women aged 19-23 (odds ratios, 0.6-0.9). After disaggregating the 18 or younger age-group, we found that infants born to mothers who were 16 or younger had reduced odds of receiving BCG vaccinations in Peru, India and Indonesia (0.4-0.8). For Nicaragua and Peru, few differences by mother's age were noted during the bivariable analyses, but covariate cell sizes allowed statistically significant differences to emerge during multivariable analysis. In particular, controlling for parity revealed

TABLE 5. Percentage of women who used skilled maternal health care, by age at last birth, according to country

\begin{tabular}{|c|c|c|c|c|c|c|c|c|}
\hline \multirow[t]{2}{*}{ Country } & \multicolumn{4}{|c|}{ Antenatal care } & \multicolumn{4}{|c|}{ Delivery care } \\
\hline & $\begin{array}{l}15- \\
16\end{array}$ & 17 & 18 & $\begin{array}{l}19- \\
23\end{array}$ & $\begin{array}{l}15- \\
16\end{array}$ & 17 & 18 & $\begin{array}{l}19 \\
23\end{array}$ \\
\hline \multicolumn{9}{|l|}{ Africa } \\
\hline Ethiopia & 28 & 33 & 29 & 25 & 11 & 13 & 7 & 7 \\
\hline Guinea & 79 & 81 & 76 & 76 & 42 & 45 & 43 & 36 \\
\hline Malawi & 93 & 94 & 94 & 93 & 61 & 62 & 56 & 58 \\
\hline Mali & 54 & 50 & 47 & 50 & 52 & 41 & 43 & 41 \\
\hline Uganda & 91 & 94 & 91 & 93 & 46 & 42 & 44 & 40 \\
\hline \multicolumn{9}{|c|}{ Latin America } \\
\hline Bolivia & 75 & 73 & 81 & 76 & 73 & 75 & 76 & 68 \\
\hline Brazil & 88 & 89 & 89 & 88 & 92 & 91 & 86 & 93 \\
\hline Guatemala & 73 & 67 & 69 & 74 & 52 & 45 & 36 & 52 \\
\hline Nicaragua & 84 & 84 & 85 & 87 & 77 & 70 & 71 & 73 \\
\hline Peru & 40 & 42 & 49 & 47 & 42 & 48 & 54 & 53 \\
\hline \multicolumn{9}{|l|}{ Asia } \\
\hline Bangladesh & 26 & 33 & 32 & 32 & 8 & 9 & 9 & 10 \\
\hline Cambodia & 37 & 42 & 49 & 41 & 30 & 30 & 43 & 39 \\
\hline India & 63 & 69 & 68 & 72 & 37 & 39 & 45 & 47 \\
\hline Indonesia & 93 & 90 & 90 & 93 & 29 & 29 & 47 & 51 \\
\hline Nepal & 59 & 63 & 59 & 58 & 13 & 24 & 21 & 18 \\
\hline
\end{tabular}




\begin{tabular}{|c|c|c|c|c|c|c|c|c|c|c|c|c|c|c|c|c|}
\hline \multirow[t]{2}{*}{ Country } & \multicolumn{4}{|l|}{ BCG } & \multicolumn{4}{|l|}{ DPT } & \multicolumn{4}{|c|}{ Measles } & \multicolumn{4}{|l|}{ Polio } \\
\hline & $15-16$ & 17 & 18 & $19-23$ & $15-16$ & 17 & 18 & $19-23$ & $15-16$ & 17 & 18 & $19-23$ & $15-16$ & 17 & 18 & $19-23$ \\
\hline \multicolumn{17}{|l|}{ Africa } \\
\hline Ethiopia & 58 & 55 & 54 & 47 & 24 & 31 & 24 & 22 & 30 & 36 & 29 & 29 & 51 & 47 & 48 & 47 \\
\hline Guinea & 72 & 76 & 77 & 72 & 42 & 41 & 45 & 40 & 56 & 53 & 52 & 52 & 38 & 38 & 42 & 35 \\
\hline Malawi & 94 & 95 & 95 & 95 & 84 & 84 & 81 & 88 & 88 & 90 & 94 & 91 & 73 & 80 & 83 & 80 \\
\hline Mali & 83 & 79 & 78 & 79 & 43 & 39 & 40 & 42 & 62 & 55 & 58 & 58 & 45 & 40 & 41 & 42 \\
\hline Uganda & 87 & 79 & 86 & 84 & 66 & 53 & 66 & 68 & 61 & 59 & 67 & 69 & 57 & 49 & 61 & 63 \\
\hline \multicolumn{17}{|c|}{ Latin America } \\
\hline Bolivia & 86 & 92 & 93 & 91 & 53 & 59 & 54 & 58 & 68 & 76 & 69 & 72 & 45 & 43 & 43 & 46 \\
\hline Brazil & 94 & 91 & 96 & 95 & 76 & 80 & 86 & 85 & 90 & 92 & 91 & 91 & 80 & 79 & 86 & 85 \\
\hline Guatemala & 89 & 88 & 88 & 91 & 71 & 73 & 68 & 78 & 90 & 84 & 82 & 85 & 68 & 68 & 61 & 73 \\
\hline Nicaragua & 93 & 95 & 95 & 95 & 78 & 82 & 84 & 87 & 88 & 88 & 92 & 94 & 81 & 84 & 89 & 89 \\
\hline Peru & 91 & 95 & 96 & 96 & 71 & 80 & 83 & 82 & 79 & 84 & 87 & 86 & 63 & 73 & 72 & 71 \\
\hline \multicolumn{17}{|l|}{ Asia } \\
\hline Bangladesh & 90 & 90 & 86 & 89 & 75 & 75 & 70 & 77 & 76 & 77 & 73 & 79 & 66 & 63 & 64 & 66 \\
\hline Cambodia & 67 & 64 & 61 & 69 & 51 & 50 & 45 & 50 & 55 & 60 & 56 & 59 & 53 & 56 & 46 & 52 \\
\hline India & 67 & 70 & 73 & 76 & 49 & 51 & 56 & 61 & 44 & 48 & 53 & 58 & 56 & 60 & 64 & 66 \\
\hline Indonesia & 67 & 84 & 87 & 85 & 47 & 55 & 59 & 66 & 59 & 68 & 72 & 76 & 72 & 76 & 76 & 77 \\
\hline Nepal & 88 & 93 & 91 & 88 & 80 & 76 & 81 & 80 & 81 & 76 & 80 & 78 & 98 & 99 & 98 & 97 \\
\hline
\end{tabular}

Notes: Percentages are weighted. Immunizations for DPT and polio are for the third shot in each series.

significant associations between age and BCG vaccination.

The largest numbers of statistically significant differences by age were detected for the third DPT and the measles vaccinations. In six countries-one in Africa (Uganda), two in Latin America (Nicaragua and Peru) and three in Asia (Bangladesh, India and Indonesia)_infants born to adolescents 18 or younger were significantly less likely to receive the third DPT shot than were infants born to older women (odds ratios, 0.6-0.8). There was a reduced likelihood of DPT vaccination for both of the younger age-groups in India and Indonesia, but only for those 16 or younger in Peru. For measles vaccinations, infants born to mothers 18 or younger had lower odds of receiving the vaccination than did those with older mothers in the same six countries (0.5-0.7). In Peru and Indonesia, differences were limited to the youngest adolescents.

Infants born to mothers 18 or younger in Uganda, Nicaragua and India were significantly less likely than were infants born to older mothers to receive their third polio vaccination (odds ratios, 0.6-0.8). After disaggregating the younger age-group, significant differences in Peru and India were limited to adolescents aged 16 or younger.

Being able to analyze the two youngest subgroups for three of the countries allowed us to identify significant differences in care between younger and older mothers that would otherwise have been masked. This is probably because the magnitude of difference between very young adolescents and older women in these countries is more powerful than the gain in statistical power from the increased cell size of the combined group of women aged 18 or younger.

\section{DISCUSSION}

Maternal age appeared to have the greatest influence on the use of maternal and child health care in Bangladesh, India and Indonesia. In particular, adolescents aged 16 or younger in India and Indonesia were less likely to use any health care than were older women. Fewer differences by age were noted in the Latin American countries, although Nicaraguan mothers aged 18 or younger and Peruvian mothers 16 or younger were less likely to use services than were older mothers. In general for the Latin American results, controlling for parity in the logistic regressions played an important role in allowing us to distinguish among the age-groups. In the African countries, there were no significant age differences in the use of skilled antenatal or delivery care; however, infants born to adolescents in Uganda were less likely to receive vaccinations than were infants born to older women.

In seeking to explain the differences in use of services by maternal age in the Asian countries, we hypothesized that women's status and decision-making power may play a role, because marriage patterns, inheritance customs and age differentials between spouses lead to women's being more disadvantaged within marriage in this region than in others. ${ }^{62}$ The indicator of socioeconomic status used in this study represents the household's assets and not the woman's ability to leverage those assets. Thus, our analysis did not control for power differentials in the household or women's status.

Women's decision-making power has been significantly and positively correlated with infant immunizations in SubSaharan Africa, Latin America and South Asia. ${ }^{63}$ Of these three regions, South Asia shows the strongest evidence of lack of decision-making power and the effects of gender inequality. If women's status and power are disproportionately lower among adolescents than among older women, ${ }^{64}$ then this may partly explain the lesser use of health services by this age-group in these countries. This hypothesis needs to be thoroughly explored at the country level.

Adolescents and older women differed in their use of DPT, measles and polio vaccinations, but less so for BCG. The BCG vaccination is administered around the time of delivery, and given that we did not find many differences in the likelihood of adolescents' use of skilled delivery care, this finding is not 


\begin{tabular}{|c|c|c|}
\hline Country & Antenatal care & Delivery care \\
\hline \multicolumn{3}{|l|}{ Africa } \\
\hline Ethiopia & $1.23(0.87-1.74)$ & $1.43(0.86-2.37)$ \\
\hline Guinea & $0.86(0.63-1.17)$ & $0.99(0.74-1.32)$ \\
\hline Malawi & $0.84(0.57-1.32)$ & $0.90(0.73-1.10)$ \\
\hline Mali & $0.81(0.61-1.07)$ & $1.90(0.78-1.53)$ \\
\hline Uganda & $1.04(0.66-1.63)$ & $1.06(0.79-1.42)$ \\
\hline \multicolumn{3}{|c|}{ Latin America } \\
\hline Bolivia & $0.85(0.57-1.26)$ & $1.56(1.05-2.32)^{*}$ \\
\hline Brazil & $0.87(0.55-1.28)$ & $0.64(0.42-0.98)^{*}$ \\
\hline Guatemala & $0.64(0.39-1.06)$ & $0.77(0.49-1.21)$ \\
\hline Nicaragua & $0.71(0.53-0.94)^{*}$ & $0.95(0.76-1.19)$ \\
\hline \multicolumn{3}{|l|}{ Peru } \\
\hline$\leq 18$ & $0.94(0.77-1.15)$ & $0.89(0.71-1.12)$ \\
\hline $17-18$ & $0.98(0.78-1.22)$ & $0.94(0.74-1.20)$ \\
\hline $15-16$ & $0.84(0.61-1.17)$ & $0.77(0.52-1.13)$ \\
\hline \multicolumn{3}{|l|}{ Asia } \\
\hline Bangladesh & $0.72(0.57-0.90)^{* *}$ & $0.54(0.38-0.77)^{* * *}$ \\
\hline Cambodia & $0.86(0.60-1.23)$ & $0.71(0.49-1.04)$ \\
\hline \multicolumn{3}{|l|}{ India } \\
\hline$\leq 18$ & $0.87(0.78-0.98)^{*}$ & $0.78(0.70-0.87)^{* *}$ \\
\hline $17-18$ & $0.93(0.82-1.04)$ & $0.82(0.73-0.93)^{* *}$ \\
\hline $15-16$ & $0.76(0.64-0.92)^{* *}$ & $0.69(0.58-0.83)^{* *}$ \\
\hline \multicolumn{3}{|l|}{ Indonesia } \\
\hline$\leq 18$ & $0.55(0.37-0.80)^{* *}$ & $0.57(0.44-0.75)^{* *}$ \\
\hline $17-18$ & $0.51(0.33-0.78)^{* *}$ & $0.62(0.45-0.84)^{* *}$ \\
\hline $15-16$ & $0.71(0.33-1.49)$ & $0.46(0.30-0.70)^{* *}$ \\
\hline Nepal & $0.89(0.70-1.14)$ & $0.75(0.53-1.08)$ \\
\hline
\end{tabular}

${ }^{*} p<.05 .{ }^{* *} p<.01$. Notes: Reference group was mothers aged 19-23; odds ratios are for all mothers aged 18 or younger unless otherwise specified. Analysis controlled for all variables listed in Table 3, plus socioeconomic status and either ethnicity, religion or language. For Nepal, marital status was excluded, owing to lack of variation; place of residence was dichotomized to rural area versus all others. For the Guinea antenatal care regression, marital status was excluded, owing to lack of variation.

surprising. However, DPT and polio require three immunizations, and the measles vaccination is given when the infant is nine months old. Another study found the greatest difference between adolescent and older mothers with the DPT vaccination, and this was attributed to behavioral differences, particularly in parental attention and effort. ${ }^{65}$

Although the DHS series offers a wealth of information, some limitations associated with these surveys may have affected our results. Respondent reports on immunizations for the three or five years preceding the survey refer to live births only; no information is collected on infants who died. If infant deaths, or even maternal deaths, are disproportionately more common among adolescents, and there is evidence that they are, ${ }^{66}$ this would result in more conservative findings for adolescents.

Interventions that have the most potential to improve outcomes for adolescents will target them before they become pregnant. Increasing adolescents' use of contraceptive methods is an important strategy, because in developing countries adolescents have twice the unmet need for family planning as do older women. ${ }^{67}$ When adolescents are already using contraceptives, access to emergency contraception could greatly reduce the likelihood of unintended pregnancy in case of method failure.
Certain general health interventions may improve outcomes when adolescents become pregnant. Services that seek to address adolescents' special needs may increase their use of maternal and child health services, although careful consideration of cost-effectiveness is needed before widespread implementation. Some reproductive health programs have begun to address the social and cultural biases against youth in clinical settings, including examination of provider attitudes, health care policies and logistical issues. However, the few studies that have focused on maternal and infant health have been limited by the lack of random assignment or baseline measures in their study designs. ${ }^{68}$

In addition to making health services more responsive to adolescents' unique needs, interventions should target adolescents in their communities. Young women are less likely than older women to know about pregnancy and reproductive health issues in general, and they have less experience in using health services. Community education about the signs and symptoms of pregnancy complications and about the benefits of seeking care is needed to increase their use of antenatal and delivery care. ${ }^{69}$

There is very little systematic evidence of programs that increase adolescents' use of maternal and child health care services. This information is particularly needed for Asian countries, where the relatively high number of pregnant adolescents underscores the public health importance of the problem. Efforts to increase women's status and decisionmaking power are needed, but so are interventions that tar-

\begin{tabular}{|c|c|c|c|c|}
\hline Country & BCG & DPT & Measles & Polio \\
\hline \multicolumn{5}{|l|}{ Africa } \\
\hline Ethiopia & $1.25(0.94-1.65)$ & $1.05(0.80-1.39)$ & $0.98(0.73-1.31)$ & $1.00(0.78-1.29)$ \\
\hline Guinea & $1.05(0.78-1.40)$ & $0.91(0.72-1.16)$ & $0.83(0.65-1.06)$ & $1.11(0.86-1.43)$ \\
\hline Malawi & $0.66(0.42-1.04)$ & $0.76(0.57-1.00)$ & $0.78(0.55-1.12)$ & $0.85(0.70-1.05)$ \\
\hline Mali & $0.98(0.63-1.52)$ & $0.83(0.63-1.10)$ & $0.95(0.70-1.30)$ & $0.85(0.64-1.13)$ \\
\hline Uganda & $0.80(0.56-1.13)$ & $0.65(0.48-0.86)^{* *}$ & $0.65(0.48-0.87)^{* *}$ & $0.71(0.54-0.93)^{* *}$ \\
\hline \multicolumn{5}{|c|}{ Latin America } \\
\hline Bolivia & $0.85(0.54-1.34)$ & $0.80(0.61-1.05)$ & $0.95(0.71-1.28)$ & $0.85(0.65-1.11)$ \\
\hline Brazil & $0.86(0.51-1.48)$ & $0.71(0.50-1.00)$ & $0.86(0.57-1.31)$ & $0.73(0.52-1.04)$ \\
\hline Guatemala & $0.72(0.42-1.25)$ & $0.72(0.49-1.05)$ & $1.14(0.76-1.72)$ & $0.72(0.49-1.05)$ \\
\hline Nicaragua & $0.60(0.39-0.94)^{*}$ & $0.59(0.46-0.77)^{* *}$ & $0.47(0.32-0.68)^{* *}$ & $0.57(0.42-0.76)^{* *}$ \\
\hline \multicolumn{5}{|l|}{ Peru } \\
\hline$\leq 18$ & $0.62(0.39-1.00)$ & $0.75(0.59-0.95)^{*}$ & $0.74(0.57-0.96)^{*}$ & $0.88(0.71-1.08)$ \\
\hline $17-18$ & $0.75(0.45-1.26)$ & $0.87(0.66-1.15)$ & $0.82(0.62-1.12)$ & $0.99(0.78-1.26)$ \\
\hline $15-16$ & $0.39(0.21-0.75)^{* *}$ & $0.49(0.35-0.70)^{* *}$ & $0.54(0.36-0.80)^{* * *}$ & $0.62(0.45-0.85)^{* * *}$ \\
\hline \multicolumn{5}{|l|}{ Asia } \\
\hline Bangladesh & $0.82(0.57-1.17)$ & $0.76(0.61-0.96)^{*}$ & $0.74(0.59-0.95)^{* *}$ & $0.86(0.70-1.06)$ \\
\hline Cambodia & $0.75(0.55-1.04)$ & $0.90(0.64-1.26)$ & $0.90(0.67-1.23)$ & $0.91(0.66-1.24)$ \\
\hline \multicolumn{5}{|l|}{ India } \\
\hline$\leq 18$ & $0.87(0.77-0.99)^{*}$ & $0.78(0.69-0.88)^{* *}$ & $0.74(0.65-0.83)^{* *}$ & $0.83(0.74-0.92)^{* *}$ \\
\hline $17-18$ & $0.91(0.79-1.05)$ & $0.80(0.70-0.92)^{* *}$ & $0.79(0.70-0.91)^{* *}$ & $0.89(0.78-1.00)$ \\
\hline $15-16$ & $0.79(0.65-0.96)^{* *}$ & $0.73(0.61-0.88)^{* *}$ & $0.61(0.51-0.74)^{* *}$ & $0.70(0.59-0.84)^{* * *}$ \\
\hline \multicolumn{5}{|l|}{ Indonesia } \\
\hline$\leq 18$ & $0.86(0.64-1.16)$ & $0.67(0.52-0.86)^{* *}$ & $0.69(0.51-0.94)^{*}$ & $1.03(0.76-1.38)$ \\
\hline $17-18$ & $1.18(0.80-1.76)$ & $0.71(0.53-0.95)^{*}$ & $0.77(0.55-1.06)$ & $1.03(0.72-1.46)$ \\
\hline $15-16$ & $0.48(0.31-0.75)^{* *}$ & $0.57(0.38-0.85)^{* *}$ & $0.55(0.35-0.85)^{* *}$ & $1.02(0.65-1.61)$ \\
\hline Nepal & $1.17(0.81-1.69)$ & $0.82(0.60-1.10)$ & $0.92(0.70-1.21)$ & $1.52(0.81-2.86)$ \\
\hline
\end{tabular}

${ }^{*} \mathrm{p}<.05 .{ }^{* *} \mathrm{p}<.01$. Notes: Reference group was mothers aged 19-23; odds ratios are for all mothers aged 18 or younger unless otherwise specified. Analysis controlled for all variables listed in Table 3, plus socioeconomic status, sex of the infant and either ethnicity, religion or language. For Nepal, marital status was excluded, owing to lack of variation; place of residence was dichotomized to rural area versus all others. 
get family members, such as men and mothers-in-law, ${ }^{70}$ which could help to increase adolescents' access in the shorter term. Furthermore, framing the importance of adolescents' access to health services in terms of the benefit to their infants may garner additional support. In Latin America, very young adolescents having first pregnancies are a key target group for reproductive health programs.

In Africa, the overall low use of maternal and child health care services and the few differences between adolescents and older women suggest that improvements in the broader organization of health services are needed. Although longterm policy interventions, such as compulsory education or increasing the legal age at marriage, may improve adolescents' pregnancy outcomes, we also need to look for solutions that will simply encourage women to seek and get maternal and child health care services.

\section{REFERENCES}

1. The Alan Guttmacher Institute (AGI), Into a New World: Young Women's Sexual and Reproductive Lives, New York: AGI, 1998.

2. Westoff CF, Trends in Marriage and Early Childbearing in Developing Countries, Calverton, MD, USA: ORC Macro, 2003.

3. Save the Children, State of the World's Mothers: 2004, Westport, CT, USA: Save the Children, 2004

4. Senderowitz J, Adolescent Health: Reassessing the Passage to Adulthood, Washington, DC: World Bank, 1995.

5. Adetoro $\mathrm{O}$ and Agah A, The implications of childbearing in postpubertal girls in Sokoto, Nigeria, International Journal of Gynecology $\mathcal{E}$ Obstetrics, 1988, 27(1):73-77; Becher H et al., Risk factors of infant and child mortality in rural Burkina Faso, Bulletin of the World Health Organization, 2004, 82(4):265-273; Hobcraft J, Fertility patterns and child survival: a comparative analysis, Population Bulletin of the UN, 1992, 33:1-31; LeGrand T and Mbacke C, Teenage pregnancy and child health in the urban Sahel, Studies in Family Planning, 1993, 24(3):137-149; Magadi M, Diamond I and Madise N, Analysis of factors associated with maternal mortality in Kenyan hospitals, Journal of Biosocial Science, 2001, 33(3):375-389; and Population Reference Bureau (PRB), The World's Youth 2000, Washington, DC: PRB, 2000.

6. McCauley AP and Salter C, Meeting the needs of young adults, Population Reports, 1995, Series J, No. 41.

7. United Nations (UN), Adolescent Reproductive Behaviour. Volume II. Evidence from Developing Countries, New York: UN, 1989.

8. Bicego G and Ahmad O, Infant and Child Mortality, Calverton, MD, USA: Macro International, 1996.

9. McCarthy J and Maine D, A framework for analyzing the determinants of maternal mortality, Studies in Family Planning, 1992, 23(1):23-33.

10. Bledsoe C and Cohen B, Social Dynamics of Adolescent Fertility in Sub-Saharan Africa, Washington, DC: National Academy Press, 1993; and Rutstein S, Sommerfelt A and Schoemaker J, Who uses maternal and child health services? evidence from the Demographic and Health Surveys, in: Child Survival Programs: Issues for the 1990s, Baltimore, MD, USA: Institute for International Programs, School of Hygiene and Public Health, Johns Hopkins University, 1990, pp. $37-84$.

11. UN, 1989, op. cit. (see reference 7); McCarthy J and Maine D, 1992, op. cit. (see reference 9); and Graham W, Bell J and Bullough C, Can skilled attendance at delivery reduce maternal mortality in developing countries? in: De Brouwere V and Van Leberghe W, eds. Safe Motherhood Strategies: A Review of the Evidence, Antwerp, Belgium: ITG Press, 2001, pp. 97-129.

12. Das Gupta M, Death clustering, mothers' education and the determinants of child mortality in rural Punjab, India, Population Stud- ies, 1990, 44(3):489-505; Kobinsky M, Conroy C and Kureshy N, Issues in Programming for Safe Motherhood, Arlington, VA, USA: Mothercare/John Snow, 2000; and Maine D et al., Why did maternal mortality decline in Matlab? Studies in Family Planning, 1996, 27(4):179-187.

13. Palloni A and Millman S, Effects of inter-birth intervals and breastfeeding on infant and early childhood mortality, Population Studies, $1986,40(2): 215-236$.

14. Committee on Improving Birth Outcomes, Board on Global Health, Improving Birth Outcomes: Meeting the Challenge in the Developing World, Washington, DC: National Academies Press, 2003.

15. Carroli G, Rooney C and Villar J, How effective is antenatal care in preventing maternal mortality and serious morbidity? an overview of the evidence, Paediatric and Perinatal Epidemiology, 2001, 15(Suppl. 1): $1-42$.

16. Alexander $\mathrm{G}$ and Korenbrot $\mathrm{C}$, The role of antenatal care in preventing low birth weight, Future of Children, 1995, 5(1):103-120.

17. Brabin L et al., Improving antenatal care for pregnant adolescents in southern Malawi, Acta Obstetricia et Gynecologica Scandinavica, 1998, 77(4):402-409.

18. Stoltzfus R, Summary: implications for research and programs, Journal of Nutrition, 2001, 131(Suppl. 2):697S-701S.

19. Okonofua F et al., Influence of socioeconomic factors on the treatment and prevention of malaria in pregnant and non-pregnant adolescent girls in Nigeria, Journal of Tropical Medicine and Hygiene, 1992, 95(5):309-315; and Steketee R et al., The problem of malaria and malaria control in pregnancy in sub-Saharan Africa, American Journal of Tropical Medicine and Hygiene, 1996, 55(Suppl. 1):2-7.

20. World Health Organization (WHO), Antenatal Care: Report of a Technical Working Group, October 31-November 4, 1994, Geneva: WHO, 1996

21. Prevention of Maternal Mortality Network, Barriers to treatment of obstetric emergencies in rural communities of West Africa, Studies in Family Planning, 1992, 23(5):279-291.

22. Bacci A et al., Outcome of teenage pregnancy in Maputo, Mozambique, International Journal of Gynecology \& Obstetrics, 1993, 40(1): 19-23; and Kumbi S and Isehak A, Obstetric outcome of teenage pregnancy in northwestern Ethiopia, East African Medical Journal, 1999, 76(3):138-140.

23. Committee on Improving Birth Outcomes, Board on Global Health, 2003, op. cit. (see reference 14).

24. Tsui AO, Wasserheit JN and Haaga JN, eds., Reproductive Health in Developing Countries: Expanding Dimensions, Building Solutions, Washington, DC: National Academy Press, 1997.

25. ORC Macro, MEASURE DHS+ model "B" questionnaire with commentary for low contraceptive prevalence countries, Calverton, MD, USA: ORC Macro, 2001

26. Farel AM and Kotch JB, The child from one to four: the toddler and preschool years, in: Kotch JB, ed., Maternal and Child Health: Programs, Problems, and Policy in Public Health, Gaithersburg, MD, USA: Aspen Publishers, 1997, pp. 115-146.

27. Thaddeus $S$ and Maine D, Too far to walk: maternal mortality in context, Social Science \& Medicine, 1994, 38(8):1091-1110.

28. Chowdhury S, Pregnancy and postpartum experience among first time young parents in Bangladesh: preliminary observations, in: Bott S et al., eds., Towards Adulthood: Exploring the Sexual and Reproductive Health of Adolescents in South Asia, Geneva: WHO, 2003, pp. 59-61.

29. Govindasamy P et al., High-Risk Births and Maternity Care, Columbia, MD, USA: Macro International, 1993.

30. Rutstein S, Sommerfelt A and Schoemaker J, 1990, op. cit. (see reference 10).

31. LeGrand T and Mbacke C, 1993, op. cit. (see reference 5).

32. Boerma J et al., Immunization: Levels, Trends and Differentials, Columbia, MD, USA: Institute for Resource Development/Macro Systems, 1990. 
33. LeGrand T and Mbacke C, 1993, op. cit. (see reference 5).

34. Rooney C, Antenatal Care and Maternal Health: How Effective Is It? A Review of the Evidence, Geneva: WHO, 1992.

35. WHO/UNFPA/UNICEF/World Bank, Reduction of Maternal Mortality: A Joint Statement, Geneva: WHO, 1999.

36. Family Care International and Safe Motherhood Inter-Agency Group, Saving Lives: Skilled Attendance at Childbirth, New York: Family Care International, 2001.

37. Gay J et al., What Works: A Policy and Program Guide to the Evidence on Family Planning, Safe Motherhood, and STI/HIV/AIDS Interventions, Washington, DC: Policy Project, 2003.

38. AbouZahr C and Wardlaw T, Maternal mortality at the end of a decade: signs of progress? Bulletin of the World Health Organization, 2001, 79(6):561-568.

39. Graham W, Bell J and Bullough C, 2001, op. cit. (see reference 11).

40. WHO, Health information package, <http://www.afro.who.int/ afropac/vpd/schedule.html>, accessed Apr. 19, 2003.

41. Boerma J et al., 1990, op. cit. (see reference 32).

42. Govindasamy P et al., 1993, op. cit. (see reference 29); and Filippi V, Graham WJ and Campbell OM, Utilizing Survey Data on Maternity Care in Developing Countries: An Illustrative Study, London: Maternal and Child Epidemiology Unit, London School of Hygiene and Tropical Medicine, 1990.

43. ORC Macro, MEASURE DHS+ STATcompiler, <http://www. measuredhs.com/statcompiler>, accessed Sept. 18, 2002.

44. Fong SF and McGovern PG, How does age affect fertility? Contemporary OB/GYN, 2004, 49:37-46.

45. Treffers $P$ et al., Care for adolescent pregnancy and childbirth, International Journal of Gynecology \& Obstetrics, 2001, 75(2):111-121.

46. LeGrand T and Mbacke C, 1993, op. cit. (see reference 5); and Gage A, Premarital childbearing, unwanted fertility and maternity care in Kenya and Namibia, Population Studies, 1998, 52(1):21-34.

47. Rutstein S, Sommerfelt A and Schoemaker J, 1990, op. cit. (see reference 10).

48. Bledsoe C and Cohen B, 1993, op. cit. (see reference 10); and Hollos M and Leis PE, Descent and permissive adolescent sexuality in two Ijo communities, Ethos, 1986, 14(4):395-408.

49. Bruce J, Married adolescent girls: numerous but unknown, neglected in policy and programs, in: Beijing +5 Meeting, New York: UNFPA, 2000; and Mathur S, Greene M and Malhotra A, Too Young to Wed: The Lives, Rights, and Health of Young Married Girls, Washington, DC: International Center for Research on Women, 2003.

50. Treffers P et al., 2001, op. cit. (see reference 45).

51. Desai S and Alva S, Maternal education and child health: is there a strong causal relationship? Demography, 1998, 35(1):71-81; and Gunaserera P and Wijesinghe P, Maternal health in Sri Lanka, Lancet, 1996, 347(9003):769.

52. Westoff CF, 2003, op. cit. (see reference 2).

53. Boerma J et al., 1990, op. cit. (see reference 32).

54. Rutstein S, Sommerfelt A and Schoemaker J, 1990, op. cit. (see reference 10).

55. Committee on Improving Birth Outcomes, Board on Global Health, 2003, op. cit. (see reference 14).

56. Leone T, Matthews Z and Dalla Zuanna G, Impact and determinants of sex preference in Nepal, International Family Planning Perspectives, 2003, 29(2):69-75.

57. World Bank Group, Poverty and health, <http://wwwl. worldbank.org/prem/poverty/health/index.htm>, accessed Apr. 20, 2003.

58. World Bank Group, Data and Methodology, <http://wwwl worldbank.org/prem/poverty/health/data/datameth2.htm>, accessed Jan. 1, 2003.
59. Ibid

60. Shah BV et al., SUDAAN's User Manual, Research Triangle Park, NC, USA: Research Triangle Institute, 1992.

61. AGI, 1998, op. cit. (see reference 1).

62. Quisumbing AR and Hallman K, Marriage in Transition: Evidence on Age, Education, and Assets from Six Developing Countries, Policy Research Division Working Papers, New York: Population Council, 2003, No. 183

63. Smith L et al., The Importance of Women's Status for Child Nutrition in Developing Countries, Washington, DC: International Food Policy Research Institute, 2003.

64. Chowdhury S, 2003, op. cit. (see reference 28).

65. LeGrand T and Mbacke C, 1993, op. cit. (see reference 5).

66. Senderowitz J, 1995, op. cit. (see reference 4).

67. Save the Children, 2004, op. cit. (see reference 3).

68. Mbonye A, Disease and health seeking patterns among adolescents in Uganda, International Journal of Adolescent Medicine and Health, 2003, 15(2):105-112; and Centre for Development and Population Activities (CEDPA), Adolescent Girls in India Choose a Better Future: An Impact Assessment, Washington, DC: CEDPA, 2001.

69. Kyomuhendo G, Low use of rural maternity services in Uganda: impact of women's status, traditional beliefs and limited resources, Reproductive Health Matters, 2003, 11(21):16-26.

70. Raju S and Leonard A, Men as Supportive Partners in Reproductive Health: Moving from Rhetoric to Reality, New Delhi, India: Population Council, 2000.

\section{RESUMEN}

Contexto: Debido a los elevados niveles de maternidad temprana en los países en desarrollo, el embarazo y el parto son las principales causas de muerte entre las mujeres de 15-19 años. El uso de atención prenatal especializada y de atención durante el parto mejora la situación de la madre mediante la prevención, el manejo y el tratamiento de las complicaciones obstétricas. Además, la inmunización de los niños evita muchas enfermedades infantiles.

Métodos: Mediante análisis de regresión logística de los datos de las Encuestas Demográficas y de Salud correspondientes a 15 países en desarrollo, se examinó el uso entre las adolescentes de los servicios de atención prenatal, de la atención durante el parto y de las inmunizaciones infantiles, en comparación con el uso que hacen de dichos servicios las mujeres con más años de edad.

Resultados: En la mayoría de los países estudiados, el uso de los servicios de atención de la salud materno-infantil no varía de acuerdo con la edad de la madre. Sin embargo, en cinco de los 15, las mujeres de 18 o menos años de edad fueron menos proclives que las de 19-23 años a recibir la atención prenatalo la atención durante el parto o ambos servicios (razones de momios de 0,5-0,9). En seis de los 15 países examinados, también fueron menos proclives las madres más jóvenes que las de más edad a inmunizar a sus hijos, en particular con la vacuna triple de la difteria, tos ferina y tétanos, y la contra el sarampión $(0,5-0,8)$. En gran medida, se limitó la asociación entre la edad y el uso de los servicios de atención de la salud a seis paísesBangladesh, India, Indonesia, Nicaragua, Perú y Uganda. En América Latina, se manifestaron unas diferencias entre las adolescentes y las mujeres de más edad una vez que se controlaban los análisis de acuerdo con la paridad. En todos los países afri- 
canos estudiados menos Uganda, no se registraron diferencias en el uso de los servicios de atención de la salud de acuerdo con la edad de la madre.

Conclusión: En el Asia, es necesario realizar trabajos de investigación a nivel de país individual para conocer mejor las razones por las cuales hay diferencias con respecto al uso de servicios materno-infantiles según la edad de la madre. En general, mayores pruebas sistemáticas asistirían a identificar las intervenciones a largo plazo que serían las más eficaces para incrementar el uso de los servicios de la salud materno-infantil por parte de las adolescentes.

\section{RÉSUMÉ}

Contexte: En raison de hauts niveaux de procréation précoce dans le monde en développement, la grossesse et l'accouchement sont les causes principales de décès des femmes de 15 à 19 ans. Le recours à des soins prénataux et obstétricaux qualifiés améliore les issues maternelles par la prévention, la gestion et le traitement des complications obstétricales, tandis que la vaccination prévient de nombreuses maladies infantiles.

Méthodes: L'analyse de régression logistique des données de l'Enquête démographique et de santé de 15 pays en développement examine le recours des adolescentes aux services de soins prénataux, de soins obstétricaux et de vaccination infantile, par rapport aux femmes plus âgées.

Résultats: Le recours aux soins de santé maternelle et infantile ne varie généralement pas en fonction de l'âge de la mère. Les femmes de 18 ans ou moins sont moins susceptibles que celles de 19 à 23 ans de recourir aux soins prénataux ou obstétricaux (ou les deux) dans cinq des 15 pays à l'étude (rapports de probabilités 0,5-0,9). Dans six pays, les mères plus jeunes sont aussi moins susceptibles que leurs aînées de faire vacciner leurs enfants, en particulier contre la diphtérie, coqueluche et tétanos et la rougeole $(0,5-0,8)$. L'association observée entre l'âge et le recours aux soins de santé est largement limitée au Bangladesh, à l'Inde, à l'Indonésie, au Nicaragua, au Pérou et a l'Ouganda. En Amérique latine, les différences entre les adolescentes et leurs aînées émergent sous contrôle de la parité. À l'exception de l'Ouganda, aucune différence n'est observée dans le recours aux soins de santé suivant l'âge de la mère dans les pays d'Afrique.

Conclusion: Pour mieux comprendre les raisons des différences de recours aux services en fonction de l'âge, des recherches spécifiques à chaque pays sont nécessaires en Asie. Une recherche systématique approfondie serait généralement utile à l'identification des interventions à long terme les plus aptes à accroître le recours des adolescentes aux services de santé maternelle et infantile.

\section{Acknowledgments}

This work was supported by Family Health International and the YouthNet project with funds from the U.S. Agency for International Development (USAID) under cooperative agreement GPH-A-0001-00013-00. Views expressed in this article do not necessarily reflect those of Family Health International or USAID. The authors are grateful to Macro International for the data used in this study, to Shyam Thapa for his contribution to study conceptualization and manuscript review, to Sarah Harbison for thoughtful comments on the analysis plan and to Barbara Janowitz for review of the analysis plan and the manuscript, as well as for her intellectual contribution throughout the process. They acknowledge Jason Smith, Patricia Bailey and Cynthia Waszak Geary for helpful comments during manuscript review; Katherin Harcum for work in data management and data analysis; Rebecca Gmach Ballantyne for contribution to the literature review; and Bosney Pierre-Louis for creating the asset index.

Author contact:hreynolds@fhi.org 